\title{
Effect of MDR1 gene promoter methylation in patients with ulcerative colitis
}

\author{
TOMOMITSU TAHARA ${ }^{1}$, TOMOYUKI SHIBATA ${ }^{1}$, MASAKATSU NAKAMURA ${ }^{1}$, HIROMI YAMASHITA ${ }^{1}$, \\ DAISUKE YOSHIOKA ${ }^{1}$, MASAAKI OKUBO ${ }^{1}$, NAOKO MARUYAMA ${ }^{1}$, TOSHIAKI KAMANO ${ }^{1}$, \\ YOSHIO KAMIYA ${ }^{1}$, YOSHIHITO NAKAGAWA ${ }^{1}$, HIROSHI FUJITA ${ }^{1}$, MITSUO NAGASAKA ${ }^{1}$, \\ MASAMI IWATA $^{1}$, KAZUYA TAKAHAMA ${ }^{1}$, MAKOTO WATANABE $^{1}$, \\ ICHIRO HIRATA $^{1}$ and TOMIYASU ARISAWA ${ }^{2}$ \\ ${ }^{1}$ Department of Gastroenterology, Fujita Health University School of Medicine, \\ 1-98 Dengakugakubo, Kutsukake-cho, Toyoake, Aichi, 470-1192; ${ }^{2}$ Department of Gastroenterology, \\ Kanazawa Medical University, 1-1 Daigaku, Uchinadamachi, Ishikawa 920-0293, Japan
}

Received November 11, 2008; Accepted December 30, 2008

DOI: 10.3892/ijmm_00000160

\begin{abstract}
Altered MDR1 expression and/or function contribute to the pathogenesis of inflammatory bowel disease (IBD). DNA methylation was shown as an important mechanism in gene silencing. We investigated DNA methylation of the MDR1 gene in ulcerative colitis (UC) and its relation to MDR1 C3435T genotypes. Eighty-three UC patients were enrolled. Methylation of MDR1 promoter was determined by methylation specific polymerase (MSP) for rectal inflammatory mucosa from all patients and normal terminal ileum from 17 patients. Promoter methylation of MDR1 gene was also quantified by digital densitographic analysis following MSP. MDR1 methylation was detected in $51(61.4 \%)$ out of 83 patients in rectal inflammatory mucosa. Mean methylation level of MDR1 gene in rectal inflammatory mucosa was significantly higher than in normal terminal ileum $(\mathrm{p}=0.021)$. MDR1 methylation occurred more frequently in total colitis, and total + left side colitis, compared to rectal colitis ( $\mathrm{p}=0.001$, 0.013 , respectively). Higher methylation levels were also associated with chronic continuous type $(\mathrm{p}=0.034)$ and earlier onset of disease $(\mathrm{p}=0.038)$. The $3435 \mathrm{CC}+\mathrm{CT}$ genotype of MDR1 was associated with more than 6-fold increased risk of MDR1 methylation, especially in UC patients with 9 years and shorter duration. Both frequency and level of MDR1 methylation were higher in UC onset at younger or in middle age with the same genotype. MDR1 methylation frequently occurred in inflammatory rectal mucosa from UC patients and was influenced by MDR1 C3435T polymorphism, especially in patients with shorter duration and younger onset.
\end{abstract}

Correspondence to: Dr Tomomitsu Tahara, Department of Gastroenterology, Fujita Health University School of Medicine, 1-98 Dengakugakubo, Kutsukake-cho, Toyoake, Aichi, 470-1192, Japan E-mail: tomomiccyu@yahoo.co.jp

Key words: ulcerative colitis, MDR1 methylation, polymorphism

\section{Introduction}

P-glycoprotein (P-gp/MDR1), encoded by the ABCB1 gene, is a $170-\mathrm{kDa}$ transmembrane protein highly expressed at the apical side of the intestinal epithelium (1). Its function is to mediate efflux of compounds from the mucosa to the gut lumen. There is increasing evidence that changes in MDR1 function and/or expression contribute to the pathogenesis of inflammatory disorders of the gastrointestinal tract (2).

Animal studies support a possible association of Mdr1 function and intestinal inflammation. Panwala et al showed that mdr1a $\mathrm{a}^{-/}$mice developed spontaneous intestinal inflammation $(3,4)$, which is further aggravated by exposure to Helicobacter bilis. Some data suggest that inflammation also results in decreased levels of intestinal Mdr1 in rats (5) and mice (6). In addition, inflammatory bowel disease (IBD)susceptibility loci were found on chromosome 7 , where the MDR1 gene is located (7). Indeed, single nucleotide polymorphisms (SNPs) in the human MDR1 gene were reported to show an association with IBD (8-10). Moreover, the low mRNA levels of MDR1 in uninflamed intestinal tissue of ulcerative colitis (UC), was reported by Langmann et al (11). These data suggest a potential association between altered functions of MDR1 and IBD.

DNA methylation was shown as an important mechanism in gene silencing. In many kinds of cancer, some genes acquire aberrant methylation in their $\mathrm{CpG}$ islands. Meanwhile, some genes are methylated in non-neoplastic tissues by aging, and this alteration is known as age-related methylation $(12,13)$. In addition, it was shown that gene methylation is present in nonneoplastic colorectal mucosa in patients with IBD $(14,15)$, esophageal mucosa in patients with Barrett's esophagitis $(16,17)$, and liver tissues in patients with chronic hepatitis (18), suggesting that gene methylation is a result of chronic inflammation.

Because loss of function of MDR1 is involved in the development of intestinal inflammation and DNA methylation accumulates during chronic inflammation, we hypothesized that DNA methylation in the MDR1 gene could be a major 
pathogenesis of IBD. In the present study, we investigated the DNA methylation status of the MDR1 gene in colonic mucosa of UC patients and its relation to various clinical phenotypes of UC. In addition we assessed its association with MDR1 C3435T polymorphism, which is associated with expression of MDR1 $(10,19,20)$, and susceptibility to UC (9).

\section{Materials and methods}

Patients and samples. The study cohort consisted of 83 UC patients enrolled at Fujita Health University Hospital (Aichi, Japan) from January 2005 to July 2007. The diagnosis of UC was based on standard clinical, endoscopic, radiological, and histo-logical criteria (21).

Clinico-pathological characteristics such as age of onset, clinical duration, and the number of times hospitalized were investigated. According to their clinical courses, chronic UC cases were classified into chronic relapsing, chronic continuous, and only one episode of the disease (22). UC patients were also classified as extensive or distal colitis according to the location and extension of the inflammatory lesions judged by endoscopic findings. In addition, patients needing continual intravenous or oral steroid therapy were identified as steroid dependent phenotype. The Ethics Committee of Fujita Health University School of Medicine approved the protocol and written informed consent was obtained from all participating subjects.

DNA isolation and bisulfite modification. Rectal inflammatory mucosal specimens were obtained from the patients and paired controls were taken from 17 patients at the normal terminal ileum. Specimens were taken during a colonoscopic biopsy and preserved in $-80^{\circ} \mathrm{C}$ until use. DNA was extracted from the specimens by blood using the standard phenol/chloroform method. To examine DNA methylation, genomic DNA was treated with sodium bisulfite using BislFast DNA Modification Kit for Methylated DNA Detection (Toyobo Co. Ltd., Osaka, Japan).

Methylation specific polymerase chain reaction. Promoter DNA methylation of MDR1 gene was determined by methylation specific polymerase chain reaction (MSP), as described previously (23). Using primers for the promoter region of MDR1 designed including six $\mathrm{CpG}$ dinucleotides that were linked to regulation of MDR1 expression (24). Primer sequences for amplification of unmethylated MDR1 were: forward 5'GGGTGTGGGTTGAGTATAGTTGTTTT-3' reverse 5'CCAACTTTACATACCCCTACCTCACA-3'; for methylated MDR1 were: forward 5'-GGGCGTGGGTTGAGTATAGT CGTTTC-3' reverse 5'-CGCTCCTTAAAACAACCACCA AAACG-3'. An annealing temperature and duration were determined using DNA from peripheral blood of a young individual and DNA methylated with SssI methylase (New England BioLabs Inc., Beverly, MA). The MSP was carried out in a volume of $20 \mu \mathrm{l}$ containing $0.1 \mu \mathrm{g}$ of bislufitemodified DNA. The DNA was denatured at $95^{\circ} \mathrm{C}$ for $5 \mathrm{~min}$, followed by 32 cycles at $95^{\circ} \mathrm{C}$ for $30 \mathrm{sec}, 56^{\circ} \mathrm{C}$ for unmethylated DNA and $60^{\circ} \mathrm{C}$ for methylated DNA for $1 \mathrm{~min}$, and $72^{\circ} \mathrm{C}$ for $1 \mathrm{~min}$ with a final extension at $72^{\circ} \mathrm{C}$ for $7 \mathrm{~min}$. The bands of MSP were detected by electrophoresis in $2.5 \%$ agarose gel stained with ethdium bromide.

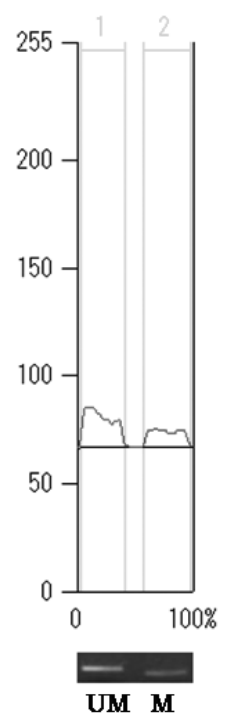

Figure1. The method of quantitive analysis of methylation levels is shown. The value of fluorescence intensities of methylated $(\mathrm{M})$ and unmethylated (UM) bands of the MDR1 promoter were measured by a digital densitometer and the methylation levels were calculated as the ratio of value of methylated bands to methylated plus unmethylated bands.

Densitographic analysis of the MDR1 gene methylation levels. The value of fluorescence intensities of methylated and unmethylated bands of the MDR1 gene were measured by a digital densitometer. The methylation levels were calculated as the ratio of the value of methylated bands to methylated plus unmethylated bands $(25,26)$ (Fig. 1).

Genotyping of MDR1 C3435T polymorphism. Genomic DNA was extracted from non-inflamed colorectal biopsy tissue or peripheral blood using the standard phenol/chloroform method in all patients. Then C3435T polymorphism of MDR1 was determined by PCR-RFLP, as previously described (27), using a forward primer (5'-tgtttcagctgcttgatgg-3') and a reverse primer (5'-aaggcatgtatgttggcctc- $\left.3^{\prime}\right)$. PCR was carried out in a reaction volume of $25 \mu \mathrm{l}$ containing $20 \mu \mathrm{g}$ of genomic DNA, 1 x reaction buffer, $0.2 \mathrm{mmol} / 1$ deoxynucleotide triphosphates, 10 pmol of each primer and 0.6 units of Taq polymerase (Toyobo, Osaka, Japan). The DNA was denatured at $95^{\circ} \mathrm{C}$ for $5 \mathrm{~min}$, followed by 35 cycles of $95^{\circ} \mathrm{C}$ for $30 \mathrm{sec}$, $63^{\circ} \mathrm{C}$ for $30 \mathrm{sec}$, and $72^{\circ} \mathrm{C}$ for $40 \mathrm{sec}$, with final extension at $72^{\circ} \mathrm{C}$ for $7 \mathrm{~min}$. Enzymatic digestion with 5 units of Mbo-I (New England Biolabs Inc., Beverly, MA) was done to analyze C3435T polymorphism, yielding products of $198 \mathrm{bp}$ (3435T) and 158+39bp (3435C). After incubation overnight at $37^{\circ} \mathrm{C}$, the products were visualized by electrophoresis on $3 \%$ agarose gel and staining with ethidium bromide.

Statistical analysis. Statistical analysis was done with twosided Fisher's exact test for the comparison of methylation frequencies between the two groups. Differences in methylation levels between the two groups of UC were examined by the Mann-Whitney U test. Differences in methylation levels between non-inflamed terminal ileum and inflamed rectal mucosa was assessed by paired Willcoxon's rank test. A p $<0.05$ was considered statistically significant. 
Table I. Characteristics of UC patients.

\begin{tabular}{lc}
\hline Subjects (number) & 83 \\
Sex [male/female $(\% / \%)]$ & $48 / 35(57.8 / 42.2)$ \\
Mean age \pm SD (year) & $40.5 \pm 13.4$ \\
\hline
\end{tabular}

MDR1 promoter methylation frequency. Promoter methylation of MDR1 gene was examined in rectal inflammatory mucosal specimens of all 83 UC patients and paired controls from 17 patients at the normal terminal ileum. The characteristics of the UC patients are summarized in Table I. First, we compared MDR1 methylation frequency between rectal inflammatory mucosa and normal terminal ileum in 17 UC patients. MDR1 methylation was detected in $16(94.1 \%)$, and $12(70.6 \%)$ out of 17 patients in rectal inflammatory mucosa and normal terminal ileum, respectively. Frequency of MDR1 methylation was higher in rectal inflammatory mucosa than in normal terminal ileum, but the difference was not significant.

In all 83 patients, MDR1 methylation was detected in 51 $(61.4 \%)$ patients in rectal inflammatory mucosa. MDR1 methylation status was not associated with gender and age. We also investigated the association between MDR1 methylation status and various clinico-pathological phenotypes of UC. Promoter of MDR1 was frequently methylated in total colitis, and total + left side colitis, compared to rectal colitis ( $\mathrm{p}=0.001,0.013$, respectively). Although the difference was not significant, the frequency of MDR1 methylation was relatively higher in chronic continuous type than chronic relapsing type $(\mathrm{p}=0.09)$ (Table II).

MDR1 promoter methylation levels in UC patients. Methylation levels of MDR1 gene were measured by digital densitographic analysis in all subjects. The methylation levels in rectal inflammatory mucosa and paired controls of the normal terminal ileum were compared in 17 patients (Fig. 2). Mean methylation level of MDR1 gene in rectal inflammatory mucosa was significantly higher than normal control $(18.9 \pm 14.4 \%$ vs $9.7 \pm 15.5 \%, \mathrm{p}=0.021)$.

Next, we investigated the association between methylation levels of MDR gene in rectal inflammatory mucosa and various clinico-pathological phenotypes of UC in all 83 subjects. The mean of methylation levels of the MDR1 gene was significantly higher in subjects with an onset before 20 years of age or younger than in subjects with an onset after 41 years of age or older $(19.5 \pm 19.2$ vs $6.4 \pm 9.8, \mathrm{p}=0.038)$. The mean methylation levels of the MDR1 gene were also higher in chronic continuous type than chronic relapsing type $(17.3 \pm 18.0 \mathrm{vs}$ $10.0 \pm 14.7, p=0.034)$. Although the difference was not significant, the mean methylation levels of the MDR1 gene correlated with the higher number of hospitalizations ( $<2$ vs $\geq 2$; $11.7 \pm 15.7$ vs $17.3 \pm 16.8, \mathrm{p}=0.085$ ) (Table III).

Association between MDRl C3435T genotypes and MDRI promoter methylation status. MDR1 C3435T polymorphism was genotyped in all 83 UC patients. The genotype distribution was $29 \mathrm{CC}, 37 \mathrm{CT}$ and $17 \mathrm{TT}$. In all 83 patients, frequency of MDR1 methylation tended to be higher in $\mathrm{CT}+\mathrm{CC}$ genotype
Table II. MDR1 promoter methylation frequency in UC patients.

\begin{tabular}{ccc}
\hline Variables (n) & $\begin{array}{c}\text { MDR1 } \\
\text { methylation (+) }\end{array}$ & $\begin{array}{c}\text { MDR1 } \\
\text { methylation (-) }\end{array}$
\end{tabular}

Non-inflamed

terminal ileum (17)

Inflammatory rectal

mucosa (17)

12

5

Gender

Male (48)

16

1

Female (35)

26

25

10

Age

$\leq 40$ years $(47)$

32

19

15

$\geq 41$ years (36)

Extension of colitis ${ }^{\mathrm{a}}$

Total colitis (39)

10

Left side colitis (21)

29

8

Rectal colitis (23)

13

9

14

Age of onset

$\begin{array}{lrr}\leq 20(15) & 12 & 3 \\ 21-40(46) & 26 & 20 \\ \geq 41(16) & 9 & 7\end{array}$

Uncertain (6)

Duration

$\geq 9$ (47)

31

16

$>10$ (30)

16

14

Uncertain (6)

Clinical type ${ }^{\mathrm{b}}$

Only one episode (5)

Chronic relapsing (49)

4 1

Chronic continuous (27)

26

Uncertain (2)

20

7

Response to treatment

Steroid-dependent or not
(+) (17)
11
6
(-) (66)
40
26

Refractory or not

$\begin{array}{lll}(+)(24) & 14 & 10 \\ (-)(59) & 37 & 22\end{array}$

32

26

$<2$ (58)

14

5

$\geq 2$ (19)

Uncertain (6)

${ }^{a}$ Total colitis vs rectal colitis, $\mathrm{p}=0.001$; total colitis + left side colitis vs rectal colitis, $\mathrm{p}=0.013$; ${ }^{\mathrm{b}}$ chronic relapsing vs chronic continuous $\mathrm{p}=0.09$. Statistical analysis was performed by two-sided Fisher's exact test.

compared to $\mathrm{TT}$ genotype $\mathrm{OR}=2.86,95 \% \mathrm{CI}=0.96-8.52$, $\mathrm{p}=0.0598$. In various various clinico-pathological phenotypes, we found that the $\mathrm{CC}+\mathrm{CT}$ genotypes held a significantly higher 


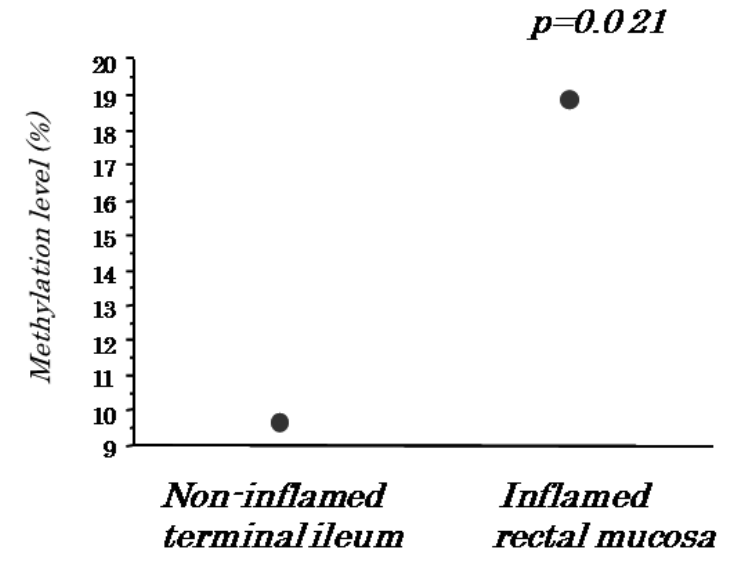

Figure 2. MDR1 methylation levels in rectal inflammatory mucosa and paired controls of the normal terminal ileum in 17 UC patients. Mean methylation level in rectal inflammatory mucosa was significantly higher than that in normal control $(18.9 \pm 14.4 \%$ vs. $9.7 \pm 15.5 \%)$. Statistical analysis was performed by the paired Willcoxon's rank test.

risk of MDR1 methylation in patients with 9 years and shorter duration $(\mathrm{OR}=6.54,95 \% \mathrm{CI}=1.74-24.57, \mathrm{p}=0.045)$ and patients with an onset at younger or in middle age (21-40 years, $\mathrm{OR}=6.27,95 \% \mathrm{CI}=1.41-27.87, \mathrm{p}=0.017 ; \geq 20+21-40$ years, $\mathrm{OR}=6.54,95 \% \mathrm{CI}=1.74-24.57, \mathrm{p}=0.005)$ (Table IV). A similar association was also observed between MDR1 methylation levels and $\mathrm{CC}+\mathrm{CT}$ genotypes in patients that onset at younger or middle ages (21-40 years, CC+CT vs TT, $\mathrm{p}=0.049$; $\geq 20+21-40$ years, $\mathrm{CC}+\mathrm{CT}$ vs TT, $\mathrm{p}=0.028$, Table V). On the other hand, frequency or levels of MDR1 methylation were not associated with MDR1 genotypes in other clinicopathological phenotypes of UC (data not shown).

\section{Discussion}

Issa et al (15) first reported that methylation of ER gene CpG island increased with age in non-neoplastic colorectal epithelium and highly methylated in colorectal epithelium from UC. Therefore, DNA methylation, as a mechanism of gene silencing, is increasing in importance contributing to the genetic alterations also in colitis associated cancer (CAC). On the other hand, Wang et al (28) showed that methylation of ER gene in rectal mucosa in UC patients was significantly higher in relapse-remitting type compared to one attack only type, and steroid-dependent cases also demonstrated a relatively higher methylated rate, suggesting the potential usefulness of DNA methylation as a molecular maker to predict disease behavior of UC.

In the present study, we investigated the promoter methylation frequency of MDR1 gene in UC patients. MDR1 methylation was observed in $61.4 \%$ from rectal inflammatory mucosal specimens of UC patients. Furthermore, methylation level of MDR1 gene in rectal inflammatory mucosa was significantly higher than in normal terminal ileum.

MDR1 is involved in the transmembrane transport of various substrates including toxic xenobiotics (29-31) and thus has a protective function in the intestinal epithelium. It was reported that mdr1 $\mathrm{a}^{-/-}$mice developed spontaneous UC-like intestinal inflammation under specific pathogen-free conditions.
Table III. Association between MDR1 promoter methylation levels and clinical phenotypes of UC.

\begin{tabular}{|c|c|}
\hline Variables (n) & $\begin{array}{l}\text { Methylation levels } \\
\quad(\text { mean } \pm \text { SD) }\end{array}$ \\
\hline \multicolumn{2}{|l|}{ Extension of colitis } \\
\hline Total colitis (39) & $13.9 \pm 15.2$ \\
\hline Left side colitis (21) & $13.6 \pm 16.2$ \\
\hline Rectal colitis (23) & $11.6 \pm 17.7$ \\
\hline \multicolumn{2}{|l|}{ Age of onset ${ }^{\mathrm{a}}$} \\
\hline$\leq 20$ years $(15)$ & $19.5 \pm 19.2$ \\
\hline $21-40$ years $(46)$ & $12.8 \pm 15.8$ \\
\hline$\geq 41$ years< $(16)$ & $6.4 \pm 9.8$ \\
\hline Uncertain (6) & \\
\hline \multicolumn{2}{|l|}{ Duration } \\
\hline$\leq 9$ years $(47)$ & $12.8 \pm 15.6$ \\
\hline$\geq 10$ years $(30)$ & $12.8 \pm 16.6$ \\
\hline Uncertain (6) & \\
\hline \multicolumn{2}{|l|}{ Clinical type $^{\mathrm{b}}$} \\
\hline Only one episode (5) & $22.4 \pm 12.6$ \\
\hline Chronic relapsing (49) & $10.0 \pm 14.7$ \\
\hline Chronic continuous (27) & $17.3 \pm 18.0$ \\
\hline \multicolumn{2}{|l|}{ Uncertain (2) } \\
\hline \multicolumn{2}{|l|}{ Response to treatment } \\
\hline \multicolumn{2}{|l|}{ Steroid-dependent or not } \\
\hline$(+)(17)$ & $15.0 \pm 17.7$ \\
\hline$(-)(66)$ & $12.7 \pm 15.6$ \\
\hline \multicolumn{2}{|l|}{ Refractory or not } \\
\hline$(+)(24)$ & $13.0 \pm 17.5$ \\
\hline$(-)(59)$ & $13.2 \pm 15.5$ \\
\hline \multicolumn{2}{|l|}{ Hospitalizations ${ }^{\#}$} \\
\hline$<2(58)$ & $11.7 \pm 15.7$ \\
\hline$\geq 2(19)$ & $17.3 \pm 16.8$ \\
\hline Uncertain (6) & \\
\hline
\end{tabular}

${ }^{\mathrm{a}}>20$ vs $>41$ years, $\mathrm{p}=0.038$; ${ }^{\mathrm{b}}$ chronic relapsing vs chronic continuous, $\mathrm{p}=0.034$; only one episode vs chronic continuous, $\mathrm{p}=0.098 ;{ }^{\mathrm{c}}<2$ vs. $\geq 2$; $\mathrm{p}=0.085$. Statistical analysis was performed by the Mann-Whitney U test.

Since $m d r 1 \mathrm{a}^{-/}$knockout mice are immunologically normal, the development of spontaneous colitis is presumably due to a defect in the barrier function of the intestinal epithelium. They also indicated that infection with Helicobacter bilis induced diarrhea, weight loss, and IBDs in mdr1 $\mathrm{a}^{-/-}$knockout mice $(3,4)$. There was also a report showing the down-regulation of MDR1 expression in colonic tissue of UC patients (11).

The MDR1 promoter region we examined by MSP includes six $\mathrm{CpG}$ dinucleotides that are linked to regulation of MDR1 expression (24). Although we did not investigate the quantitive difference of MDR1 in colonic mucosa of UC patients, it is possible that MDR1 methylation might affect the MDR1 expression. Our data suggest that MDR1 methylation occurs through chronic inflammation and further is involved in UC, altering the activity and expression of MDR1. 
Table IV. MDR1 C3435T genotypes in relation to MDR1 promoter methylation in UC patients.

\begin{tabular}{|c|c|c|c|}
\hline Variables (n) & $\begin{array}{c}\text { MDR1 } \\
\text { genotypes (n) }\end{array}$ & $\begin{array}{c}\text { MDR1 } \\
\text { methylation(+) }\end{array}$ & $\begin{array}{c}\text { MDR1 } \\
\text { methylation(-) }\end{array}$ \\
\hline \multirow[t]{3}{*}{ Overall UC $\mathrm{UC}^{\mathrm{a}}$ (83) } & CC (29) & 19 & 10 \\
\hline & CT (37) & 25 & 12 \\
\hline & TT (17) & 7 & 10 \\
\hline \multicolumn{4}{|l|}{ Age of onset ${ }^{b}$} \\
\hline \multirow[t]{3}{*}{$\leq 20$ years $(15)$} & $\mathrm{CC} \quad$ (5) & 5 & 0 \\
\hline & $\mathrm{CT} \quad(8)$ & 6 & 2 \\
\hline & $\mathrm{TT} \quad(2)$ & 1 & 1 \\
\hline \multirow[t]{3}{*}{$21-40$ years $(46)$} & CC (17) & 11 & 6 \\
\hline & CT (17) & 12 & 5 \\
\hline & TT (12) & 3 & 9 \\
\hline \multirow[t]{3}{*}{$\geq 41$ years $(16)$} & $\mathrm{CC}$ & 3 & 1 \\
\hline & $\mathrm{CT}$ & 4 & 5 \\
\hline & TT (3) & 0 & 3 \\
\hline \multicolumn{4}{|l|}{ Duration $^{\mathrm{c}}$} \\
\hline \multirow[t]{3}{*}{$\leq 9$ years $(47)$} & CC (19) & 13 & 6 \\
\hline & CT (19) & 15 & 4 \\
\hline & $\mathrm{TT}$ & 3 & 6 \\
\hline \multirow[t]{3}{*}{$\geq 10$ years $(30)$} & $\mathrm{CC} \quad$ (7) & 4 & 3 \\
\hline & $\mathrm{CT} \quad(15)$ & 8 & 7 \\
\hline & TT (8) & 4 & 4 \\
\hline
\end{tabular}

${ }^{\mathrm{a}} \mathrm{CC}+\mathrm{CT}$ vs TT, OR $(95 \% \mathrm{CI}) \mathrm{p}=2.86(0.96-8.52) \mathrm{p}=0.0598$; ${ }^{\mathrm{b}} \geq 9$ years, TT vs CC+CT, OR $(95 \% \mathrm{CI}) \mathrm{p}=6.54(1.74-24.57) \mathrm{p}=0.045 ;{ }^{c} 21-40$ years, $\mathrm{CC}+\mathrm{CT}$ vs TT, OR $(95 \% \mathrm{CI}) \mathrm{p}=6.27(1.41-27.87) \mathrm{p}=0.017 ; \geq 20+21-40$ years, CC+CT vs TT, OR $(95 \% \mathrm{CI}) \mathrm{p}=6.54(1.74-24.57) \mathrm{p}=0.005 . \mathrm{Statistical}$ analysis was performed by two-sided Fisher's exact test.

Table V. Association between MDR1 C3435T genotypes and MDR1 promoter methylation levels in UC patients.

\begin{tabular}{lcc}
\hline Variables (n) & $\begin{array}{c}\text { MDR1 genotypes } \\
(\mathrm{n})\end{array}$ & $\begin{array}{c}\text { MDR1 methylation levels } \\
(\text { mean } \pm \text { SD) }\end{array}$ \\
\hline Overall UC (83) & CC (29) & $14.5 \pm 14.4$ \\
& CT (37) & $13.8 \pm 17.5$ \\
& CC+CT (66) & $14.8 \pm 16.1$ \\
& TT (17) & $9.7 \pm 15.7$ \\
Age of onset ${ }^{\mathrm{a}}$ & & \\
$\leq 20$ years (15) & $\mathrm{CC}+\mathrm{CT}(13)$ & $20.7 \pm 19.9$ \\
& $\mathrm{TT}(2)$ & $11.7 \pm 16.5$ \\
$21-40$ years (46) & $\mathrm{CC}+\mathrm{CT}(34)$ & $16.3 \pm 16.8$ \\
& $\mathrm{TT}(12)$ & $8.4 \pm 15.7$ \\
$\geq 41$ years (16) & $\mathrm{CC}+\mathrm{CT}(13)$ & $4.3 \pm 6.6$ \\
& $\mathrm{TT}(3)$ & $15.6 \pm 17.7$ \\
\hline
\end{tabular}

a21-40 years, $\mathrm{CC}+\mathrm{CT}$ vs TT, $\mathrm{p}=0.049 ;>20+21-40$ years, $\mathrm{CC}+\mathrm{CT}$ vs TT, $\mathrm{p}=0.028$. Statistical analysis was performed by Mann-Whitney U test.

We also investigated the association between MDR1 methylation status and various clinical phenotypes of UC. We found that the hypermethylation of MDR1 was associated with chronic continuous type. In addition, we found a positive association between MDR1 methylation and several severe disease phenotypes. Frequency of MDR1 methylation was significantly higher in extensive colitis phenotypes than in rectal colitis. Methylation levels of the MDR1 gene were higher in patients with an onset at 20 years of age or younger than in subjects with an onset after 41 years of age or older. Furthermore, higher methylation levels tended to correlate with higher number of hospitalizations.

$\mathrm{UC}$ is diverse in its clinical course, prognosis, and response to treatment, thus, it was hypothesized that UC is a syndrome in which different pathogenic mechanisms lead to various clinical phenotypes and it may be necessary to place greater emphasis on the disease heterogeneity. As we know, extensive colitis phenotypes and patients that developed the disease at younger age show more severe disease behavior and often need more intensive clinical treatment. This result indicates that different UC subgroups have different epigenetic backgrounds. Our result of association between MDR1 methylation status and certain clinical phenotypes of UC in the easily accessible rectum also indicates the potential usefulness of MDR1 methylation as a molecular marker to conduct more appropriate clinical implementation reflecting an individual's pathophysiology.

We also investigated whether the MDR1 methylation status in rectal mucosa might be affected by MDR1 C3435T 
genotypes. We found that the $\mathrm{CC}+\mathrm{CT}$ genotype was associated with more than 6-fold increased risk of MDR1 methylation, especially in UC patients with 9 years and shorter duration. In addition we also found that both frequency and level of MDR1 methylation were significantly higher in UC at an onset at younger or in middle age with the same genotypes.

The MDR1 gene is located on chromosome 7 at q21.1 (32), one of the loci of susceptibility to IBD is identified by a genome-wide analysis in a UK cohort (7). The linkage in this region was confirmed by genome scan meta-analysis (33). Finally, in 2003-2005, independent groups in Germany and Scotland indicated that a C3435T polymorphism in exon 26 is associated with susceptibility to UC but not to CD $(9,34)$. In Japanese, 3435TT and T allele associated with UC only in patients who developed the disease at older age (19). Regarding the MDR1 expression in the gastrointestinal tract, it was reported that healthy, Japanese subjects with TT genotype showed a higher level of MDR1 expression in the duodenum compared to other genotypes (20). A similar result was also observed in rectal mucosa with an earlier onset UC patients (19).

The mechanism of gene methylation seems to be related to the chronic cycles of injury, inflammation, repair and rapid turnover of the colonic epithelia (35). Our data suggest that the CC and CT genotypes, associated with a low expression of MDR1, result in impairment for repair of MDR1, and is less protective against such conditions. Thus, these genotypes may be susceptible to MDR1 gene methylation. On the other hand, we did not find such an association in patients with longer duration and later onset. Other genetic or environmental factors may influence the susceptibility to gene methylation in such phenotypes.

In regard to the effect of MDR1 C3435T polymorphism on MDR1 expression, although TT genotype was reported to have higher expression of MDR1 in healthy, Japanese subjects (20), it should be emphasized that some of the studies have yielded contradictory results $(10,20,36-38)$. Among five published studies, three reported decreased expression $(10,36,37)$, and two found increased expression of MDR1 $(20,38)$ in association with this polymorphism. Because the functional role of this polymorphism varies among the different studies and the possible functional effect of silent C3435T polymorphism is still unknown, further studies using in vivo and ex vivo systems will be needed to resolve this issue.

In conclusion, we showed that MDR1 methylation frequently occurs in inflammatory rectal mucosa from UC patients and correlated with chronic continuous type and severe disease phenotypes such as extensive colitis phenotypes and patients that developed the disease at 20 years of age or younger. Furthermore, we showed that the MDR1 methylation status in rectal mucosa was influenced by MDR1 C3435T poly-morphism especially in UC with shorter duration and an onset at younger and in middle age. This is the first investigation on the potential association between MDR1 methylation and UC in relation to MDR1 genotypes. Our results show that further longitudinal studies of aberrant DNA methylation are needed.

\section{References}

1. Thiebaut F, Tsuruo T, Hamada H, Gottesman MM, Pastan I and Willingham MC: Cellular localization of the multidrugresistance gene product P-glycoprotein in normal human tissues. Proc Natl Acad Sci USA 84: 7735-7738, 1987.

2. Ho GT, Moodie FM and Satsangi J: Multidrug resistance 1 gene (P-glycoprotein 170): an important determinant in gastrointestinal disease? Gut 52: 759-766, 2003.

3. Banner KH, Cattaneo C, Le Net JL, Popovic A, Collins D and Gale JD: Macroscopic, microscopic and biochemical characterisation of spontaneous colitis in a transgenic mouse, deficient in the multiple drug resistance 1a gene. Br J Pharmacol 143: 590-598, 2004.

4. Wilk JN, Bilsborough J and Viney JL: The $\operatorname{mdr} 1 \mathrm{a}^{-/}$mouse model of spontaneous colitis: a relevant and appropriate animal model to study inflammatory bowel disease. Immunol Res 31: 151-160, 2005.

5. Kalitsky-Szirtes J, Shayeqanpour A, Brocks DR and Piquette-Miller M: Suppression of drug-metabolizing enzymes and efflux transporters in the intestine of endotoxin-treated rats. Drug Metab Dispo 32: 20-27, 2004.

6. Buyse M, Radeva G, Bado A and Farinotti R: Intestinal inflammation induces adaptation of P-glycoprotein expression and activity. Biochem Pharmacol 69: 1745-1754, 2005.

7. Satsangi J, Parkes M, Louis E, et al: Two stage genome-wide search ininflammatory bowel disease provides evidence for susceptibility loci onchromosomes 3,7 and 12. Nat Genet 14: 199-202, 1996.

8. Brant SR, Panhuysen CI, Nicolae D, et al: MDR1 Ala893 polymorphism is associated with inflammatory bowel disease. Am J Hum Genet 73: 1282-1292, 2003.

9. Schwab M, Schaeffeler E, Marx C, et al: Association between the C3435T MDR1 gene polymorphism and susceptibility for ulcerative colitis. Gastroenterology 124: 26-33, 2003.

10. Hoffmeyer S, Burk O, von Richter O, et al: Functional polymorphisms of the human multidrug-resistance gene: multiple sequence variations and correlation of one allele with $\mathrm{P}$ glycoprotein expression and activity in vivo. Proc Natl Acad Sci USA 97: 3473-3478, 2000.

11. Langmann T, Moehle C, Mauerer R, et al: Loss of detoxification in inflammatory bowel disease: dysregulation of pregnane X receptor target genes. Gastroenterology 127: 26-40, 2004.

12. Issa JP, Ottaviano YL, Celano P, Hamilton SR, Davidson NE and Baylin SB: Methylation of the oestrogen receptor $\mathrm{CpG}$ island links ageing and neoplasia in human colon. Nat Genet 4: 536-540, 1994 .

13. Ahuja N, Li Q, Mohan AL, Baylin SB and Issa JP: Aging and DNA methylation in colorectal mucosa and cancer. Cancer Res 23: 5489-5494, 1998 .

14. Sato F, Harpaz N, Shibata D, et al: Hypermethylation of the p14 (ARF) gene in ulcerative colitis-associated colorectal carcinogenesis. Cancer Res 62: 1148-1151, 2002.

15. Issa JP, Ahuja N, Toyota M, Bronner MP and Brentnall TA: Accelerated age-related $\mathrm{CpG}$ island methylation in ulcerative colitis. Cancer Res 61: 3573-3577, 2001.

16. Bian YS, Osterheld MC, Fontolliet C, Bosman FT and Benhattar J: p16 inactivation by methylation of the CDKN2A promoter occurs early during neoplastic progression in Barrett's esophagus. Gastroenterology 122: 1113-1121, 2002.

17. Wong DJ, Paulson TG, Prevo LJ, et al: p16 (INK4a) lesions are common, early abnormalities that undergo clonal expansion in Barrett's metaplastic epithelium. Cancer Res 61: 8284-8289, 2001.

18. Kaneto H, Sasaki S, Yamamoto H, et al: Detection of hypermethylation of the p16(INK4A) gene promoter in chronic hepatitis and cirrhosis associated with hepatitis B or C virus. Gut 48: 372-377, 2001.

19. Osuga T, Sakaeda T, Nakamura T, et al: MDR1 C3435T polymorphism is predictive of later onset of ulcerative colitis in Japanese. Biol Pharm Bull 29: 324-329, 2006.

20. Nakamura T, Sakaeda T, Horinouchi M, et al: Effect of the mutation (C3435T) at exon 26 of the MDR1 gene on expression level of MDR 1 messenger ribonucleic acid in duoden enterocytes of healthy Japanese subjects. Clin Pharmacol Ther 71: 297-303, 2002

21. Podolsky DK: Inflammatory bowel disease 2. N Engl J Med 325: 928-937, 1991. 
22. Langholz E, Munkholm P, Davidsen M and Binder V: Course of ulcerative colitis: analysis of changes in disease activity over years. Gastroenterology 107: 3-11, 1994.

23. Van Rijnsoever M, Grieu F, Elsaleh H, Joseph D and Iacopetta B: Characterisation of colorectal cancers showing hyper-methylation at multiple CpG islands. Gut 51: 797-802, 2002.

24. Tada Y, Wada M, Kuroiwa K, et al: MDR1 gene overexpression and altered degree of methylation at the promoter region in bladder cancer during chemotherapeutic treatment. Clin Cancer Res 6: 4618-4627, 2000.

25. Arisawa T, Tahara T, Shibata T, et al: Promoter hypomethylation of protease-activated receptor 2 associated with carcinogenesis in the stomach. J Gastroenterol Hepatol 22: 943-948, 2007.

26. Tahara T, Arisawa T, Shibata T, et al: Risk prediction of gastric cancer by analysis of aberrant DNA methylation in non-neoplastic gastric epithelium. Digestion 75: 54-61, 2007.

27. Drozdzik M, Bialecka M, Mysliwiec K, Honczarenko K, Stankiewicz J and Sych Z: Polymorphism in the P-glycoprotein drug transporter MDR1 gene: a possible link between environmental and genetic factors in Parkinson's disease. Pharmacogenetics 13: 259-263, 2003 .

28. Wang FY, Arisawa T, Tahara T, et al: Aberrant DNA methylation in ulcerative colitis without neoplasia. Hepatogastroenterology 55: 62-65, 2008

29. Higgins $\mathrm{CF}$ : $\mathrm{ABC}$ transporters: from microorganisms to man. Annu Rev Cell Biol 8: 67-113, 1992.

30. Van Veen HW and Konings WN: The ABC family of multidrug transporters in microorganisms. Biochim Biophys Acta 1365: 31-36, 1998
31. Dean M, Rzhetsky A and Allikmets R: The human ATP-binding cassette $(\mathrm{ABC})$ transporter superfamily. Genome Res 11: 1156-1166, 2001.

32. Callen DF, Baker E, Simmers RN, Seshadri R and Roninson IB: Localization of the human multiple drug resistance gene, MDR1, to 7q21.1. Hum Genet 77: 142-144, 1987.

33. Van Heel DA, Fisher SA, Kirby A, Daly MJ, Rioux JD and Lewis CM; Genome scan meta-analysis group of the IBD International Genetics Consortium: Inflammatory bowel disease susceptibility loci defined by genome scan meta-analysis of 1952 affected relative pairs. Hum Mol Genet 1: 763-770, 2004.

34. Ho GT, Nimmo ER, Tenesa A, et al: Allelic variations of the multidrug resistance gene determine susceptibility and disease behavior in ulcerative colitis. Gastroenterology 128: 288-296, 2005.

35. Moss SF and Blaser MJ: Mechanisms of disease: Inflammation and the origins of cancer. Nat Clin Pract Oncol 2: 90-97, 2005.

36. Kim RB, Leake BF, Choo EF, et al: Identification of functionally variant MDR1 alleles among European Americans and African Americans. Clin Pharmacol Ther 70: 189-199, 2001.

37. Fellay J, Marzolini C, Meaden ER, et al: Response to antiretroviral treatment in HIV-1-infected individuals with allelic variants of the multidrug resistance transporter 1: a pharmacogenetics study. Lancet 359: 30-36, 2002.

38. Hitzl M, Drescher S, van der Kuip H, et al: The C3435T mutation in the human MDR1 gene is associated with altered efflux of the P-glycoprotein substrate rhodamine 123 from CD56+ natural killer cells. Pharmacogenetic 11: 293-298, 2001. 